\title{
UJI EFEKTIVITAS NEMATODA ENTOMOPATOGEN (RHABDITIDA: Steinernema DAN Heterorhabditis) SEBAGAI MUSUH ALAMI NON-ENDEMIK PENGGEREK BATANG PADI KUNING (Scirpophaga incertulas)
}

\author{
Chaerani $^{1}$ dan Bebet Nurbaeti ${ }^{2}$
}

\begin{abstract}
Efficacy Tests of Entomopathogenic Nematodes (Rhabditida: Steinernema dan Heterorhabditis) as Non-endemic Natural Enemies of Yellow Rice stem Borer (Scirpophaga incertulas). Yellow rice stem borer (Scirpophaga incertulas) is a chronic insect pests of irrigated rice and difficult to control. Entomopathogenic nematodes from the genus Steinernema and Heterorhabditis are promising biological control agents for this pest as their infective juveniles (IJs) are capable of seeking and infecting insect living in moist, cryptic habitat such as galleries created by stem borer larvae. Thirteen indigenous and exotic Steinernema and Heterorhabditis sprayed to rice seedlings in laboratory with nematodes at concentrations of 0.5 or $2.0 \times 10^{4} \mathrm{IJs} \mathrm{ml}^{-1}$ water caused larval mortality between $7-93 \%$. Further test in greenhouse on nematodes that had $>50 \%$ efficacy showed that an indigenous isolate, $H$. indicus INA H17, was the most effective among the tested nematodes in killing larvae or pupae $(78 \%)$. Reduction in plant damage caused by the insects could not be demonstrated as the trials was limited to potted plants. The survival ability of nematodes on rice plants was evaluated by using INA $\mathrm{H} 4$ as an example. A low percentage of INA H4 IJs $(0.5 \%)$ persisted in inner leaf sheath until 7 days post application, while IJs on leaf surface and outer leaf sheath survived only until 2 and 48 hours post application, respectively. Improvement of application strategies including repeated spray, addition of antidessicant and adjusment of spray volume and application at damage threshold or plant critical period are deemed necessary to enhance nematode efficacy and reduce plant damage in the field.
\end{abstract}

Key words: entomopathogenic nematodes, yellow rice stem borer, biological control

\section{PENDAHULUAN}

Diantara enam jenis penggerek batang padi yang dikenal di Indonesia, penggerek batang padi kuning (Scirpophaga incertulas) merupakan spesies yang paling dominan (Soejitno, 1991). Imago meletakkan telur di daun. Segera setelah menetas larvanya menggerek ke dalam batang masuk dari pelepah daun, kemudian hidup hingga menjadi pupa di dalam batang dengan memakan jaringan dalam batang (Khan et al., 1991). Bila serangan terjadi pada stadia vegetatif, tunas yang sedang tumbuh menjadi kering, coklat dan gagal membuka; gejalanya dikenal sebagai 'sundep'. Serangan pada fase generatif menimbulkan kehilangan hasil yang besar karena gerekan larva menyebabkan terpotongnya pangkal malai sehingga gabah menjadi hampa. Bulir gabah yang hampa tampak berwarna putih dan gejalanya disebut 'beluk' (Soejitno, 1991).

Serangan penggerek batang efektif dikendalikan dengan penaburan karbofuran, insektisida anjuran bersifat sistemik, akan tetapi penggunaannya yang tidak bijaksana telah menimbulkan resistensi pada penggerek batang padi putih (Scirpophaga innotata) di beberapa wilayah pantai utara Jawa Barat (Soejitno et al., 1994). Cara lain yang dilakukan petani adalah menggenangi singgang untuk mematikan larva dan pupa namun cara ini tidak efektif karena lubang gerekan tertutup oleh jalinan benang sutera yang tidak tembus air (Khan et al. 1991). Feromon seks sintetik dapat menjadi cara pengendalian yang efektif namun hingga kini belum tersedia di pasaran (Hendarsih \& Usyati, 1999).

Pengendalian secara hayati dengan musuh alami aman terhadap lingkungan dan tidak menimbulkan resistensi serangga. Salah satu jenis musuh alami yang non-endemik di pertanaman padi adalah nematoda dari genus Steinernema dan Heterorhabditis (Rhabditida: Steinernematidae dan Heterorhabditidae). Kedua genus dapat menjadi agen pengendalian hayati yang efektif untuk PBPK karena mempunyai banyak keunggulan. Stadia infektifnya, yaitu juvenil instar-3 atau biasa disebut juvenil infektif (JI), memiliki hampir semua karakter yang diperlukan sebagai musuh alami yang ideal, antara lain: mampu mencari serangga di dalam tanah atau di

${ }^{1}$ Balai Besar Penelitian Bioteknologi dan Sumberdaya Genetik Pertanian (BB-Biogen), Jl. Tentara Pelajar No. 3A Bogor 16111, Tel. 0251-337975, 339793, Fax. 0251-338820, e-mail: r.chaerani@yahoo.com

${ }^{2}$ Balai Pengkajian Teknologi Pertanian Jawa Barat, Jl. Kayu Ambon No. 80 Lembang 40391 
dalam habitat tersembunyi (cryptic habitat), mempunyai virulensi dan daya reproduksi tinggi, menyebabkan kematian serangga <48 jam sehingga dapat membatasi aktivitas makan serangga dan mencegah kerusakan lebih lanjut, dan dapat dikembangbiakkan pada serangga ataupun media buatan dengan biaya relatif murah (Kaya \& Gaugler, 1993). Kemampuan patogeniknya diperoleh dari simbiosis mutualistik dengan bakteri Xenorhabdus spp. atau Photorhabdus spp. yang sel-selnya tersimpan dalam saluran pencernaan JI (Kaya \& Gaugler, 1993). Kompleks nematoda-bakteri ini menyebabkan kematian serangga dengan cara meracuni darah (septicemia). Aplikasi nematoda entomopatogen (NE) di alam tidak berdampak negatif terhadap jasad bukan sasaran termasuk seranggaserangga berguna, vertebrata dan manusia (Boemare et al., 1996).

Uji efektivitas NE terhadap hama-hama yang hidup di permukaan tanah dalam habitat tersembunyi telah banyak dilaporkan, antara lain di luar negeri yaitu terhadap penggerek batang padi (Rao \& Rao, 1980) dan penggerek batang Mexico (Eoreuma loftini) pada jagung (Ring \& Browning, 1990), dan di Indonesia yaitu terhadap Plutella xylostella pada kubis (Lisnawita et al., 2000) dan pengorok daun Lyriomyza huidobrensis pada krisan (Yulensri et al., 2001). Serangga yang hidup dalam habitat demikian sulit dijangkau oleh kebanyakan insektisida sehingga lebih efektif dikendalikan dengan NE (Begley, 1990; Jansson et al., 1990; Lisnawita et al., 2000; Yulensri et al., 2001).

Penelitian ini bertujuan mendapatkan NE yang potensial mengendalikan penggerek batang padi kuning. Sejumlah NE asal Indonesia dan introduksi ditapis di laboratorium dan rumah kaca secara in planta.

\section{METODE PENELITIAN}

\section{Serangga Uji dan Tanaman Padi}

Ngengat PBPK hasil tangkapan di Leuwiliang (Bogor), dilepas pada tanaman padi dalam pot yang telah disungkup dengan plastik mylar berkasa. Ngengat dibiarkan bertelur kemudian kelompok telurnya diletakkan pada cawan petri dan dibiarkan menetas. Sepuluh atau 20 ekor larva instar-1 (L-1) diinfestasikan pada tanaman padi varietas IR64 berumur 30 hari setelah tebar (HST) yang ditanam dalam gelas plastik bervolume $240 \mathrm{ml}$ dan pada tanaman padi IR64 berumur 60 HST yang ditanam pada pot berupa ember plastik bergaris tengah $25 \mathrm{~cm}$. Tanaman disungkup dengan plastik mylar berkasa selama seminggu sebelum diperlakukan dengan nematoda.

\section{Pembiakan Nematoda Entomopatogen}

NE yang diuji terdiri dari isolat Indonesia koleksi BB-Biogen (Griffin et al., 2000; Chaerani et $a l ., 2007)$ dan introduksi. NE diperbanyak pada larva Tenebrio molitor (Coleoptera: Tenebrionidae) menggunakan metode infeksi kertas saring yang dirancang untuk skala massal (Chaerani \& Griffin, 2007). JI dipanen setiap dua hari sekali kemudian disimpan dalam air dalam cawan-cawan Petri berdiameter $15 \mathrm{~cm}$. Cawan-cawan Petri ini diletakkan di dalam inkubator bersuhu $10^{\circ} \mathrm{C}$ (Sanyo MIR-151). Umur simpan JI pada saat digunakan dalam percobaan tidak lebih dari 3 minggu.

\section{Efikasi Nematoda Entomopatogen}

Uji di Laboratorium.Tanaman muda dalam gelas plastik $(240 \mathrm{ml})$ yang telah diinfestasi dengan 10 ekor L-1 disemprot dengan JI yang telah disuspensikan dalam air ditambah dengan bahan perata Triton X-100 (Sigma $\left.{ }^{\circledR}\right)$ sebanyak $0.1 \% \quad(\mathrm{v} / \mathrm{v})$. Sebagian besar nematoda diaplikasikan pada konsentrasi $2.0 \times 10^{4} \mathrm{JI}$ $\mathrm{ml}^{-1}$ air, sedangkan $S$. glaseri pada $0.5 \times 10^{4} \mathrm{JI} \mathrm{ml}^{-1}$ air karena tidak diperoleh jumlah JI yang cukup. Penyemprotan menggunakan alat semprot tangan (Tudor®). Tanaman yang disemprot dengan air saja dan dengan air ditambah $0.1 \%$ Triton X-100 digunakan sebagai pembanding. Kematian larva diamati seminggu kemudian. Larva yang mati terinfeksi oleh Heterorhabditis berwarna coklat kemerahan dan berpendar dalam keadaan gelap sedangkan yang terinfeksi oleh Steinernema berwarna krem kehijauan. Untuk memastikan penyebab kematian larva yang menunjukkan gejala kematian tidak khas dibedah di bawah mikroskop stereo dengan perbesaran 30-60×. Rancangan percobaan yang digunakan adalah Rancangan Acak Lengkap (RAL) dengan 8 ulangan.

Uji di rumah kaca. Nematoda yang dapat mematikan $>50 \%$ larva pada uji laboratorium diuji lanjut di 
rumah kaca. Tanaman padi yang ditanam dalam ember dan telah diinfestasi dengan 20 ekor L-1 seminggu sebelumnya disemprot dengan suspensi nematoda dalam air ditambah dengan bahan perata Triton X-100 sebanyak 0.1\% (v/v). Penyemprotan dilakukan setelah pukul 16.00 menggunakan alat semprot bertekanan (Hozelock® berkapasitas 1.51 ). Tanaman yang disemprot dengan air saja dan dengan air ditambah $0.1 \%$ Triton X-100 digunakan sebagai pembanding.

Percobaan dilaksanakan dua kali. Pada percobaan Rumah Kaca I (RK I) nematoda diaplikasikan pada konsentrasi $2.0 \times 10^{4} \mathrm{JI} \mathrm{ml}^{-1}$ air. Penyemprotan diulangi seminggu kemudian, kecuali untuk $S$. carpocapsae \#25, yang hanya diaplikasikan satu kali karena terbatasnya jumlah JI yang diproduksi. Tujuh hari setelah aplikasi (HSA) NE yang kedua dilakukan pembelahan batang untuk pengamatan 1) persentase kematian PBPK, dan 2) persentase kerusakan batang tanaman (gejala sundep dan batang tergerek). Percobaan menggunakan Rancangan Acak Kelompok dengan 10 ulangan.

Percobaan RK II pada dasarnya sama dengan RK I tetapi sedikit dimodifikasi yaitu 1) tidak semua NE dapat diaplikasikan, 2) nematoda diaplikasikan

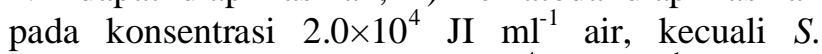

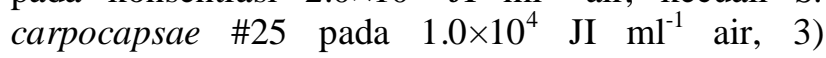
percobaan dilaksanakan hanya dalam 5 ulangan karena jumlah JI yang terbatas, dan 4) tanaman disemprot dengan air setiap hari mulai satu hari setelah aplikasi nematoda hingga sehari sebelum pengamatan untuk mempertahankan kelembaban batang. Hal ini dilakukan karena pada RK I tingkat kematian $<15 \%$, kemungkinan karena pelepah batang bagian dalam terlalu kering (lihat Hasil dan Pembahasan).

\section{Daya Bertahan Nematoda Entomopatogen pada Tanaman Padi}

Percobaan ini dilakukan untuk mengetahui lama kemampuan dan lokasi bertahan JI pada tanaman padi. Untuk itu salah satu NE, $H$. indicus INA H4, dengan konsentrasi $2.0 \times 10^{4} \mathrm{JI} \mathrm{ml}^{-1}$ air ditambah dengan $0.1 \%$ Triton X-100 (v/v) disemprotkan pada lima tanaman padi berumur 60 HST yang ditanam dalam ember di rumah kaca. Satu jam setelah penyemprotan dilakukan pengambilan sampel JI dari permukaan daun, pelepah batang bagian luar dan pelepah batang bagian dalam. Untuk itu spons berukuran $1 \mathrm{~cm}^{3}$ yang telah dibasahi diusapkan pada masing-masing permukaan daun dan pelepah batang bagian luar dari satu batang terpilih per pot. Spons kemudian direndam dalam syracuse berisi air selama satu malam untuk memberi kesempatan semua JI yang terperangkap dalam poripori spons keluar. Batang terpilih tersebut kemudian dipotong pada batas permukaan air dan selanjutnya dipotong-potong sepanjang $1 \mathrm{~cm}$. Potongan batang direndam semalam dalam syracuse berisi air untuk mengeluarkan JI yang berada di dalam batang. Air rendaman spons dan batang diamati di bawah mikroskop stereo perbesaran 30-60× untuk pengamatan persentase JI yang hidup. JI dianggap hidup apabila bergerak setelah disentuh dengan ujung jarum. Tenggang waktu antara perendaman sampel spons dan batang hingga pengamatan diasumsikan tidak berpengaruh terhadap laju mortalitas JI. Pengambilan sampel berikutnya dilakukan setiap 24 jam hingga hari ke-7 setelah penyemprotan.

\section{Analisis statistika}

Data kematian larva PBPK dianalisis menggunakan prosedur ANOVA dari GenStat ${ }^{\circledR} 6$ (Payne et al., 2002). Sebelum dianalisis data ditransformasi ke dalam arcsin $\sqrt{(Y / 100)}$ untuk menstabilkan keragaman. Uji Beda Nyata Terkecil (BNT) pada $P=0.05$ digunakan untuk membedakan rata-rata antar perlakuan nematoda.

\section{HASIL DAN PEMBAHASAN}

\section{Efikasi Nematoda Entomopatogen di Laboratorium}

Perbedaan antar NE dalam menyebabkan kematian larva sangat nyata $(P<0.01)$. Sebagian besar Heterorhabditis spp. lebih efektif dibandingkan dengan sebagian besar Steinernema, dengan menyebabkan kematian larva $>50 \%$ (Tabel 1). Pengecualian terlihat pada $H$. indicus P2M dan $S$. carpocapsae \#25. Dibandingkan dengan Heterorhabditis lainnya P2M hanya mampu menyebabkan kematian PBPK sebesar $31 \%$. Sementara itu $S$. carpocapsae \#25 adalah yang paling efektif di antara Steinernema lainnya dengan menyebabkan kematian hampir $60 \%$ larva.

Efektivitas Heterorhabditis yang pada umumnya lebih tinggi dibandingkan dengan Steinernema juga telah dilaporkan sebelumnya (misalnya Bedding \& Miller, 1981; Molyneux et al., 
1983; Georgis \& Poinar, 1984; Mannion \& Jansson, 1993b; Chaerani \& Waluyo, 1996). Mobilitas dan infektivitas Heterorhabditis dilaporkan lebih baik dibandingkan dengan kebanyakan Steinernema (Schroeder \& Beavers, 1987; Mannion \& Jansson, 1993a). Sementara itu S. carpocapsae, spesies Steinernema yang mempunyai ukuran tubuh yang mirip dengan kebanyakan Heterorhabditis spp. merupakan nematoda yang efektif terhadap berbagai serangga hama sehingga beberapa strainnya telah dikomersialkan, (Kaya \& Gaugler, 1993).

\section{Efikasi Nematoda Entomopatogen di Rumah Kaca}

NE yang memperlihatkan efektivitas $>50 \%$ pada percobaan di laboratorium diuji kembali di rumah kaca. Repetisi percobaan terlihat berpengaruh nyata $(P<0.01)$ sehingga data percobaan RK I dan II dianalisis secara terpisah. Pada kedua percobaan aplikasi NE berpengaruh nyata terhadap kematian PBPK ( $P=0.018$ untuk RK I dan $P=0.005$ untuk RK II), tetapi tidak mampu mengurangi terjadinya gejala sundep ( $P=0.837$ untuk RK I dan $P=0.736$ untuk RK II). Stadia larva dan pupa keduanya dapat terinfeksi oleh nematoda.

Pada RK I persentase kematian PBPK terlihat lebih rendah dibandingkan dengan yang terdapat pada
RK II (Tabel 1). Penyemprotan air pasca aplikasi nematoda pada RK II berhasil meningkatkan persentase kematian serangga. Akan tetapi pengaruh positif dari perlakuan pasca penyemprotan ini tidak berlaku untuk semua NE karena korelasi antara kedua percobaan rumah kaca tidak nyata $\left(r^{2}=0.046 ; t=0.62\right.$; $P>0.05$ ).

Persentase kematian PBPK pada kedua percobaan rumah kaca jauh lebih rendah dibandingkan dengan yang terjadi di laboratorium. Korelasi antara tingkat kematian PBPK antara percobaan RK I dengan laboratorium dan RK II dengan laboratorium juga tidak nyata; $r^{2}$ berturut-turut $0.002(t=-0.151$; $P>0.05)$ dan $0.020(t=-0.399 ; P>0.05)$. Penurunan efektivitas NE yang besar di rumah kaca dibandingkan dengan di laboratorium dapat diakibatkan oleh desikasi yang cepat ditambah oleh radiasi surya dan paparan suhu yang cenderung tinggi pada tanaman rumah kaca. Hal ini dapat dimengerti karena habitat alami NE adalah tanah sehingga prasyarat utama kondisi optimum agar NE dapat menginfeksi, yaitu kelembaban relatif $>90 \%$ dan tersedianya lapisan air bebas, harus ada pada permukaan tanaman untuk membantu nematoda mencapai lubang gerek (Begley, 1990).

Untuk mengetahui nematoda yang paling efektif

Tabel 1. Efektivitas Heterorhabditis dan Steinernema terhadap penggerek batang padi kuning di laboratorium

\begin{tabular}{|c|c|c|c|c|}
\hline Nematoda & Sumber $^{1}$ & Konsentrasi aplikasi & \multicolumn{2}{|c|}{ Kematian larva } \\
\hline H. indicus INA H3 & 1 & 2,0 & 98,2 & $\mathrm{a}$ \\
\hline H. indicus INA H4 & 1 & 2,0 & 88,5 & $a b$ \\
\hline H. bacteriophora EU222 & 3 & 2,0 & 79,5 & $a b$ \\
\hline H. bacteriophora HP88 & 3 & 2,0 & 69,1 & $a-c$ \\
\hline H. indicus INA H1 & 1 & 2,0 & 62,9 & $a-d$ \\
\hline S. carpocapsae \#25 & 2 & 2,0 & 59,7 & $a-d$ \\
\hline H. indicus INA H17 & 1 & 2,0 & 54,2 & a-d \\
\hline H. indicus $\mathrm{P} 2 \mathrm{M}$ & 3 & 2,0 & 30,9 & $b-d$ \\
\hline Steinernema INA S21 & 1 & 2,0 & 14,6 & $\mathrm{~cd}$ \\
\hline S. glaseri & 3 & 2,0 & 14,6 & $\mathrm{~cd}$ \\
\hline Steinernema INA S14 & 1 & 0,5 & 14,6 & $\mathrm{~cd}$ \\
\hline Steinernema MACAU & 3 & 2,0 & 14,6 & $\mathrm{~cd}$ \\
\hline Steinernema INA S3 & 1 & 2,0 & 7,3 & $\mathrm{~d}$ \\
\hline Triton X-100 (0.1\%) & - & - & 0,0 & $\mathrm{~d}$ \\
\hline Air & - & - & 0,00 & $\mathrm{~d}$ \\
\hline
\end{tabular}

${ }_{1}^{1}$ =BB-Biogen (isolat Indonesia), 2=Biosys, Inc., 3=National University of Ireland.

${ }^{2}$ Ditambah bahan perata $(0.1 \%$ Triton X-100).

${ }^{3}$ Rata-rata dari 8 ulangan. Hasil transformasi balik dari $\arcsin \sqrt{ }(Y / 100)$. 
dilakukan penghitungan rata-rata keseluruhan dari kedua percobaan dengan cara memboboti rata-rata (weighted mean) kematian PBPK untuk tiap perlakuan dari masing-masing percobaan dengan nilai keragaman (Kearsey \& Pooni, 1996). Dari rata-rata kematian terboboti terlihat bahwa $H$. indicus INAH17 merupakan nematoda yang paling efektif pada kondisi rumah kaca (78\%), sementara nematoda yang lain hanya mampu menyebabkan kematian PBPK <10\% (Tabel 2).

Keragaman dalam efektivitas di antara dan dalam spesies nematoda (antar strain atau isolat) timbul sebagai hasil adaptasi terhadap lingkungan dan serangga inang alaminya. Oleh karena itu untuk mendapatkan nematoda yang sesuai terhadap suatu jenis serangga beberapa spesies, isolat dan strain perlu ditapis sekaligus. Sebagai contoh keberhasilan penggunaan NE ialah aplikasi strain $H$. bacteriophora dan $S$. carpocapsae yang tepat dapat menurunkan kepadatan populasi hama lanas (Cylas formicarius) pada ubi jalar dan kerusakan umbi di lapang (Jansson et al., 1990). Sementara itu Ring \& Browning (1990) mendapatkan S. carpocapsae strain 'All' yang dapat membunuh $83 \%$ larva penggerek batang Mexico (Eoreuma loftini) setelah membandingkan efektivitas tiga spesies NE. Sebaliknya penggunaan strain nematoda yang tidak sesuai diduga telah menjadi penyebab rendahnya efektivitas $S$. carpocapsae DD136 terhadap penggerek padi kepala hitam (Rao et al., 1971) dan gagalnya pengendalian kumbang Jepang Popilia japonica di lapang (Georgis \& Gaugler 1991).

Aplikasi NE, walaupun efektif mematikan

Tabel 2. Efektivitas Heterorhabditis dan Steinernema terhadap penggerek batang padi kuning di rumah kaca

\begin{tabular}{|c|c|c|c|c|c|c|c|}
\hline \multirow[b]{2}{*}{ Nematoda } & \multicolumn{3}{|c|}{ Percobaan I } & \multicolumn{3}{|c|}{ Percobaan II } & \multirow[b]{2}{*}{$\begin{array}{c}\text { Rata-rata } \\
\text { kematian } \\
\text { terboboti } \\
(\%)^{4}\end{array}$} \\
\hline & $\begin{array}{c}\text { Konsentrasi } \\
\text { aplikasi } \\
\left(\times 10^{4} \mathrm{JI} \mathrm{ml}^{-1}\right. \\
\text { air })^{1} \\
\end{array}$ & $\begin{array}{c}\text { Gejala } \\
\text { sundep } \\
(\%)\end{array}$ & $\begin{array}{c}\text { Kematian } \\
\text { serangga } \\
(\%)^{2}\end{array}$ & $\begin{array}{c}\text { Konsentrasi } \\
\text { aplikasi } \\
\left(\times 10^{4} \mathrm{JI} \mathrm{ml}^{-1}\right. \\
\text { air })^{1} \\
\end{array}$ & $\begin{array}{c}\text { Gejala } \\
\text { sundep } \\
(\%)\end{array}$ & $\begin{array}{c}\text { Kematian } \\
\text { serangga } \\
(\%)^{3}\end{array}$ & \\
\hline $\begin{array}{l}\text { H. indicus INA } \\
\text { H17 }\end{array}$ & 2.0 & 29,9 & $3,5 b$ & 2,0 & 25,1 & $9,12 \mathrm{a}$ & 78,1 \\
\hline $\begin{array}{l}\text { S. carpocapsae } \\
\# 25\end{array}$ & 2.0 & 30,0 & $13,3 \mathrm{a}$ & 1,0 & 26,5 & $4,3 \mathrm{de}$ & 8,7 \\
\hline $\begin{array}{l}\text { H. indicus INA } \\
\mathrm{H} 3\end{array}$ & 2.0 & 36,7 & $3,5 b$ & 2,0 & 26,7 & $51,9 \mathrm{bc}$ & 6,1 \\
\hline $\begin{array}{l}\text { H. indicus INA } \\
\mathrm{H} 1\end{array}$ & 2.0 & 40,1 & $1,7 \mathrm{bc}$ & 2,0 & 24,7 & $42,9 b-d$ & 2,9 \\
\hline $\begin{array}{l}\text { H. bacteriophora } \\
\text { EU222 }\end{array}$ & 2.0 & 33,9 & $0,1 \mathrm{bc}$ & 2,0 & 31,9 & $55,1 \mathrm{~b}$ & 0,4 \\
\hline $\begin{array}{l}\text { H. bacteriophora } \\
\text { HP88 }\end{array}$ & 2.0 & 34,0 & $0,5 \mathrm{bc}$ & NT & NT & NT & 0,5 \\
\hline $\begin{array}{l}\text { H. indicus INA } \\
\mathrm{H} 4\end{array}$ & 2.0 & 32,9 & $0,4 \mathrm{bc}$ & 2,0 & 17,3 & 20,6b-e & 0,5 \\
\hline $\begin{array}{l}\text { Kontrol (Triton } \\
\mathrm{X}-1000.1 \% \text { ) }\end{array}$ & - & 30,7 & $0,0 \mathrm{c}$ & - & 27,2 & $4,3 c-e$ & 4,3 \\
\hline Kontrol (air) & - & 31,3 & $0.0 \mathrm{c}$ & - & 30,4 & $0,0 \mathrm{e}$ & 0,0 \\
\hline
\end{tabular}

${ }^{1}$ Ditambah bahan perata (0.1\% Triton X-100).

${ }^{2}$ Rata-rata dari 10 ulangan; hasil transformasi balik dari arcsin $\sqrt{ }(Y / 100)$. Nematoda diaplikasikan dua kali dengan selang waktu 7 hari.

${ }^{3}$ Rata-rata dari 5 ulangan; hasil transformasi balik dari arcsin $\sqrt{ }(Y / 100)$. Kecuali S. carpocapsae \#25, semua nematoda diaplikasikan dua kali dengan selang waktu seminggu.

${ }^{4}$ Dihitung menggunakan rumus: $\sum\left(Y_{i} / s^{2}{ }_{i}\right) / \sum\left(1 / s_{i}^{2}\right)$, dimana $Y$ adalah rata-rata kematian serangga dan $s^{2}$ adalah keragaman. 
PBPK, tidak berpengaruh terhadap pengurangan gejala serangan PBPK. Penyebab pertama, aplikasi NE dilakukan seminggu setelah infestasi larva penggerek. Pada kurun waktu ini sudah terjadi kerusakan tanaman yang cukup besar, sehingga penggunaan NE tidak lagi dapat menekan gejala kerusakan. Kedua, percobaan hanya dilakukan dalam skala pot di rumah kaca. Larva PBPK diketahui berpindah-pindah tanaman beberapa kali sebelum berkepompong (Kalshoven, 1981). Percobaan skala mikprolot oleh Rao \& Rao (1980) membuktikan bahwa aplikasi $S$. carpocapsae DD-136 mampu mengurangi gejala sundep hingga menjadi 5-9\% walaupun efektivitas NE tersebut hanya 2-6\%. Penyebab ketiga, tanaman sudah melewati fase vegetatif sehingga tidak mampu beregenerasi; dengan jumlah anakan yang relatif tetap persentase kerusakan akan tampak besar. Implikasi praktis dari percobaan rumah kaca ini untuk aplikasi di lapangan ialah NE harus diaplikasikan pada waktu yang tepat, misalnya pada ambang kerusakan tanaman untuk penyemprotan insektisida (Hendarsih et al., 1997) atau pada fase kritis tanaman terhadap serangan penggerek (Rauf et al. 1992), agar diperoleh penekanan kerusakan tanaman yang maksimal.

\section{Kemampuan Bertahan Nematoda Entomopatogen pada Tanaman Padi}

Laju penurunan JI $H$. indicus INA $\mathrm{H} 4$ hidup pada pelepah daun bagian dalam pada 24 dan 48 JSA lebih lambat, masing-masing 53 dan $68 \%$, bila dibandingkan dengan laju penurunan pada permukaan daun $(100 \%)$ dan pelepah bagian luar (58 dan $90 \%$; Gambar 1). Bahkan JI hidup dan aktif masih dapat ditemukan pada pelepah bagian dalam hingga hari ke7 setelah penyemprotan walaupun hanya $0.5 \%$. Sementara itu pada pelepah bagian luar JI hidup tidak dijumpai lagi pada 48 JSA.

Pada ketiak pelepah bagian dalam air biasanya dapat tertampung sehingga dapat menjadi lokasi ideal

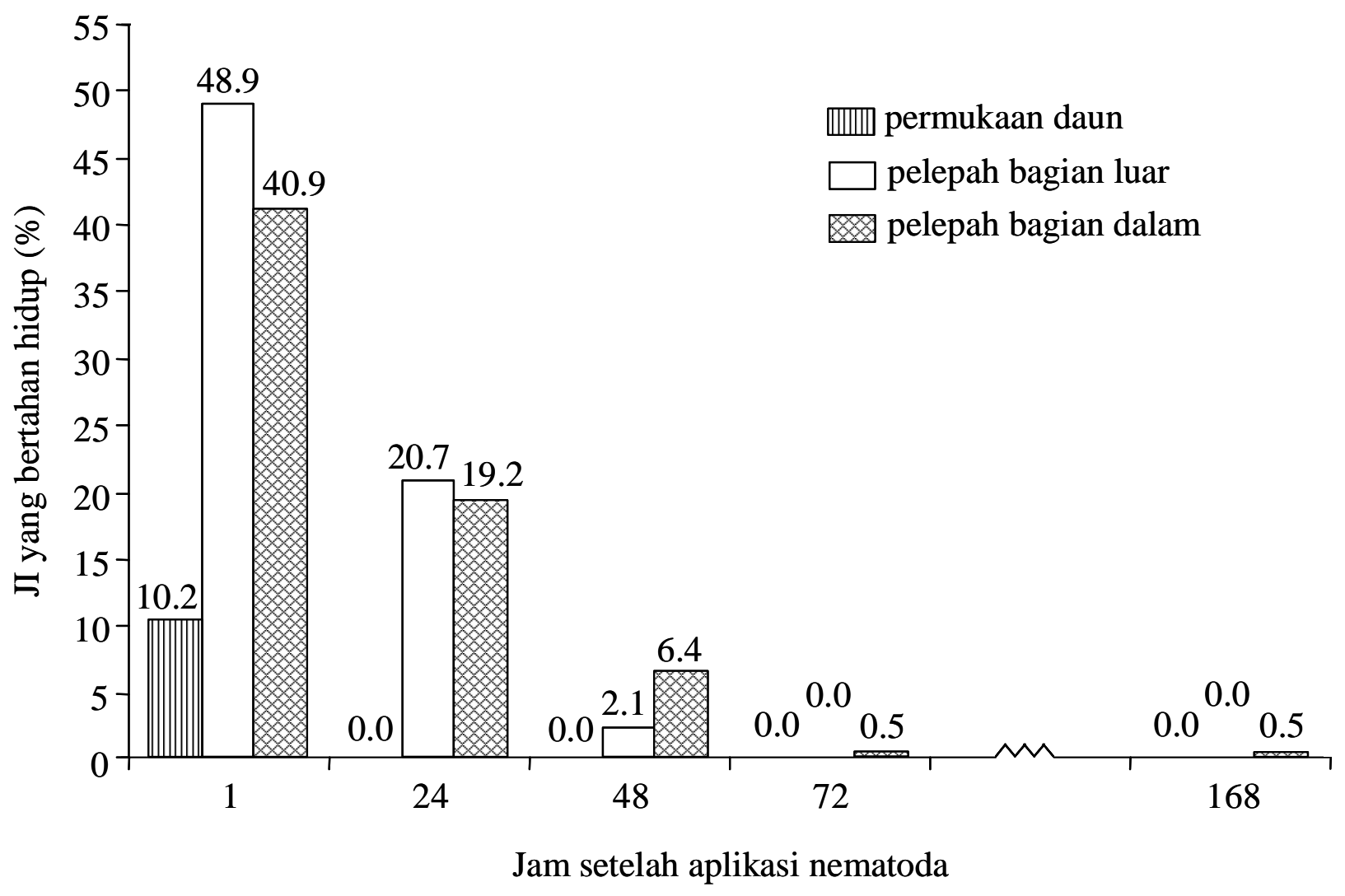

Gambar 1. Persentase juvenil infektif (JI) Heterorhabditis indicus INA H4 yang bertahan hidup pada tanaman padi. Rata-rata dari 5 tanaman. 
bagi NE menunggu datangnya larva yang akan menggerek. Air juga dapat masuk dan membasahi bagian dalam pelepah sehingga menjadi sarana bergerak nematoda ke dalam batang melalui lubang masuk larva dan mengikuti lorong gerekan mencari serangga sasaran. Pengulangan aplikasi NE, penambahan antidesikan atau bahan pemekat dan penambahan volume air akan dapat mengkompensasi kehilangan nematoda dan memperpanjang masa hidup nematoda pada tanaman (Begley, 1990). Untuk aplikasi di lapangan penyemprotan air pasca aplikasi nematoda tidak diperlukan karena selain tidak praktis, biasanya terjadi kondensasi pada tanaman yang dapat membantu menciptakan lapisan air bebas pada permukaan tanaman.

\section{SIMPULAN DAN SARAN}

Kemampuan NE untuk menginfeksi PBPK yang berada dalam batang telah ditunjukkan dalam penelitian ini sehingga NE berprospek baik sebagai musuh alami non-endemik PBPK. $H$. indicus INA H17 merupakan nematoda yang paling efektif di antara 13 NE yang diuji dengan menyebabkan kematian PBPK sebesar 78\%. Penurunan gejala kerusakan tanaman akibat aplikasi NE tidak terlihat dalam percobaan skala pot ini. Pelepah bagian dalam batang tanaman padi merupakan lokasi bertahan yang paling baik bagi NE dimana JI hidup masih dapat ditemukan hingga 7 HSA.

Strategi aplikasi NE yang disarankan untuk mendapatkan efektivitas pengendalian PBPK dan pengurangan kerusakan tanaman yang maksimum antara lain 1) mengulangi aplikasi, sebaiknya dengan selang waktu tidak lebih dari 7 hari, 2) menambah antidesikan atau bahan pemekat dan menambah volume semprot untuk memperpanjang masa hidup nematoda, dan 3) mengaplikasikan NE di lapangan pada ambang kerusakan tanaman atau fase kritis tanaman.

\section{SANWACANA}

Penghargaan yang sebesar-besarnya kami tujukan kepada Juanda, Tutom dan Tatang atas bantuan di rumah kaca dan kepada C. Vercollino (Biosys, Inc., Illinois, U.S.A.) dan Dr. C. Griffin (National University of Ireland, Maynooth, Ireland) atas sumbangan isolat nematoda introduksi.

\section{DAFTAR PUSTAKA}

Bedding, R.A. \& L.A. Miller. 1981. Use of a nematode Heterorhabditis heliothidis, to control black vine weevil, Otiorhynchus sulcatus, in potted plants. Ann. appl. Biol. 99: 211-216.

Begley, J.W. 1990. Efficacy against insects in habitats other than soil. Pages 215-231 in: Gaugler, R. \& H.K. Kaya, eds. Entomopathogenic Nematodes in Biological Control. CRC Press, Inc. Boca Raton, Florida.

Boemare, N., C. Laumond, \& H. Mauleon. 1996. The entomopathogenic nematode-bacterium complex: biology, life cycle and vertebrate safety. Biocontrol Sci. and Tech. 6(3): 333-345.

Chaerani \& C.T. Griffin. 2007. Perbanyakan massal nematoda entomopatogen Heterorhabditis indicus secara in vivo. J. Penel. Pertan. (in press).

Chaerani \& Waluyo. 1996. Potensi nematoda patogen serangga Steinernema dan Heterorhabditis (Rhabditida: Steinernematida, Heterorhabditidae) sebagai pengendali hayati hama lanas ubi jalar (Cylas formicarius) $\mathrm{F}$. (Coleoptera: Apionidae). Seminar Nasional Pengendalian Hayati Yogyakarta, 25-26 November 1996.

Chaerani, Y. Suryadi, T.P. Priyatno, D. Koswanudin, U. Rahmat, Sujatmo, Yusuf, \& C.T. Griffin. 2007. Isolasi nematoda patogen serangga Steinernema dan Heterorhabditis. J. Hama dan Peny. Tumb. Trop. (in press).

Georgis, R. \& G.O. Poinar, Jr. 1984. Greenhouse control of the black vine weevil Otiorhynchus sulcatus (Coleoptera: Curculionidae) by heterorhabditid and steinernematid nematodes. Environ. Entomol. 13(4): 1138-1140.

Georgis, R. \& R. Gaugler. 1991. Predictability in biological control using entomopathogenic nematodes. J. Econ. Entomol. 84(3): 713-720. 
Griffin, C.T., R. Chaerani, D. Fallon, A.P. Reid, and M.J. Downes. 2000. Occurrence and distribution of the entomopathogenic nematode Steinernema spp. and Heterorhabditis indica in Indonesia. J. Helminthol. 74(2): 143-150.

Hendarsih, S. \& N. Usyati. 1999. Perangkap feromon seks untuk pengendalian penggerek batang padi kuning. J. Perlind. Tan. Ind. 5(2): 77-82.

Hendarsih, S., N. Usyati, \& A. Rahayu. 1997. Hubungan hasil tangkapan perangkap seks feromon dengan tingkat serangan batang padi kuning (Scirpophaga incertulas Wlk). Prosiding Seminar Nasional PEI, Bogor, 8 Januari 1997.

Jansson, R.K., S.H. Lecrone, R. Gaugler \& G.C. Smart, Jr. 1990. Potential of entomopathogenic nematodes as biological control agents of sweetpotato weevil (Coleoptera: Curculionidae). J. Econ. Entomol. 83(5): 1818-1826.

Kalshoven, L.G.E. 1981. Pests of crops in Indonesia. PT Ichtiar Baru van Hoeve. Jakarta.

Kaya, H.K. \& R. Gaugler. 1993. Entomopathogenic nematodes. Annu. Rev. Entomol. 38: 181-206.

Kearsey, M.J. \& H.S. Pooni. 1996. The Genetical Analysis of Quantitative Traits. Chapman \& Hall. London.

Khan, Z.R., J.A. Barrion, F.F.D. Villaneuva, N.J. Fernandez, \& L.D. Taylo. 1991. World bibliography of rice stem borers 1794-1990. IRRI \& ICIPE.

Lisnawita, M.C. Tobing, D. Bakti, \& I. Safni. 2000. Potensi Steinernema carpocapsae Weiser untuk pengendalian hayati Plutella xylostella (L.) (Lepidoptera: Plutellidae) pada tanaman kubis (Brassica oleracea). J. Penel. Pertan. 21(2): 8994.

Mannion, C.M. \& R.K. Jansson. 1993a. Infectivity of five entomopathogenic nematodes to the sweetpotato weevil, Cylas formicarius (F.), Coleoptera: Apionidae) in three experimental arenas. J. Invertebr. Pathol. 62(1): 29-36.
Mannion, C.M. \& R.K. Jansson. 1993b. Within-root mortality of Cylas formicarius (Coleoptera: Apionidae) by entomopathogenic nematodes. $J$. Econ. Entomol. 86(3): 722-729.

Molyneux, A.S., R.A. Bedding, \& R.J. Akhurst. 1983. Susceptibility of larvae of the sheep blowfly, Lucilia cuprina to various Heterorhabditis spp., Neoaplectana spp., and an undescribed steinernematid (Nematoda). J. Invertebr. Pathol. 43(1): 1-7.

Payne, R.W., S.A. Harding, D.A. Murray, D.M. Soutar, D.B. Baird, S.J. Welham, A.F. Kane, A.R. Gilmour. R. Thompson, R. Webster, \& G.T. Wilson. 2002. GenStat ${ }^{\circledR}$ for Windows TM $6^{\text {th }}$ Edition. Oxford, VSN International.

Rao, Y.R.V.J. \& Y.S. Rao. 1980. Suitability tests with indigenous and exotic natural enemies on Chilo auricilius Dudgn. in the laboratory. Indian J. Agric. Res. 14(3): 169-179

Rao, Y.R.V.J., P.S.P. Rao, A. Varma, \& P. Israel. 1971. Tests with an insect parasitic nematode DD-136 (Nematoda: Steinernematidae) against the rice stem borer, Tryporyza incertulas Walker. Indian J. Entomol. 33(3): 215-217

Rauf, A., I.W. Winasa, R. Anwar, A. Tarigan, \& J. Lestari. 1992. Kajian beberapa teknik pengendalian penggerek batang padi putih Scirpophaga innotata (Lepidoptera: Pyralidae). Seminar Hasil Penelitian Pendukung Pengendalian Hama Terpadu, Cisarua, 7-8 September.

Ring, D.R. \& H.W. Browning. 1990. Evaluation of entomopathogenic nematodes against the Mexican rice borer (Lepidoptera: Pyralidae). $J$. Nematol. 22(3): 420-422

Schroeder, W.J. \& J.B. Beavers. 1987. Movement of the entomogenous nematodes of the families Heterorhabditidae and Steinernematidae in soil. J. Nematol. 19(2): 257-259.

Soejitno, J. 1991. Bionomi dan pengendalian hama penggerek padi, halaman 713-716 dalam: 
Soenarjo, E., D.S. Damarjati, \& M. Syam eds. Buku Padi 3. Pusat Penelitian dan Pengembangan Tanaman Pangan. Bogor.

Soejitno, J., I.M. Samudra \& D. Kilin. 1994. Kajian Ketahanan Penggerek Padi Putih, Scirpophaga innotata Walker terhadap Insektisida Karbofuran. Penelitian Pertanian 14(2): 78-83.
Yulensri, T. Santoso, A. Rauf, \& Chaerani. 2001. Uji keefektifan nematoda entomopatogen Heterorhabditis indicus dan Steinernema riobravis terhadap hama pengorok daun Liriomyza huidobrensis (Blanchard) (Diptera: Agromyzidae). Simposium Pengendalian Hayati Serangga, Sukamandi, 14-15 Maret 2001. 